\author{
International \\ Journal of Thy hical

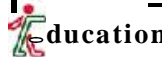 \\ DOI : $10.15740 / \mathrm{HAS} / \mathrm{IJPE} / 9.1 \& 2 / 5-9$ \\ e ISSN-0976-7924 Visit us : www.researchjournal.co.in \\ Research Paper
}

Volume 9 | Issue $1 \& 2$ | April \& October, 2016 | 5-9

\title{
Survey of nutritional assessment in relation to waist to hip ratio and waist to height ratio among school going children
}

\section{PRADEEP SINGH CHAHAR}

Received : 06.05.2016; Revised : 03.09.2016; Accepted : 18.09.2016

Author for correspondence

PRADEEP SINGH CHAHAR Department of Physical Education, Manipal University, JAIPUR (RAJASTHAN) INDIA

\section{-ABSTRACT}

The purpose of this study was to survey the nutritional status in relation to waist-to hip ratio and waist to height ratio among school going children of Gwalior city.A total of hundred $(n=100)$ male subjects from KendriyaVidyalayas of Gwalior city studying in classes from $10^{\text {th }}$ to $12^{\text {th }}$ standard with age ranged from 14 to 18 years were selected for this study. All the subjects were examined for nutritional status, waist hip ratio and waist to height ratio. Results revealed that majority of subjects in waist hip ratio fall under the ideal-very low risk, while extremely slim category in waist to height ratio. Further, pearson product moment correlation result revealed that nutritional status was significantly correlated with waist to hip ratio $(-0.340 ; p<0.05)$ and insignificantly correlated with waist to height ratio $(-0.073 ; \mathrm{p}>0.05)$. Therefore, it may be concluded that waist hip ratio can be used as a predictor for nutritional deficiencies. There are many plausible reasons behind the school going childrens' being suffering from indecent nutritional status. Developing good practices early in life, will benefited in future.

- KEY WORDS : Nutritional status, Waist to hip ratio, Waist to height ratio

- HOW TO CITE THIS PAPER : Chahar, Pradeep Singh (2016). Survey of nutritional assessment in relation to waist to hip ratio and waist to height ratio among school going children. Internat. J. Phy. Edu., 9 (1\&2) : 5-9, DOI : 10.15740/HAS/IJPE/9.1\&2/5-9. 